\title{
Developments on the Fire Propagation Test
}

DR. AKASHA M. AZHAKESAN, DR. T. J. SHIELDS and MR. G. W. H. SILCOCK

University of Ulster

Fire Sert Centre, 75 Belfast Road

Carrickfergus, Co. Antrim, BT38 8PH

\begin{abstract}
The Fire Propagation test, BS 476, Part 6 was developed to assess a lining material's potential contribution to fire growth in an enclosure based on the material's notional heat release profile and is assessed by means of indices derived from measurements of the flue gas temperature.
\end{abstract}

The apparatus was modified to include measurements of mass loss and oxygen consumption to enable calculation of heat release parameters. Air flows into the naturally ventilated enclosure systems were derived from exhaust gas measurements and variations in system combustion efficiencies were identified.

Investigations reveal that the Fire Propagation test environment addresses crucial features of a wall lining's heat contribution to a dynamically changing fire environment in enclosures. The derived test performance indicators reflect in a single test, the fire response characteristics of the material with respect to the three generic material types tested, namely, plasterboards, fire retarded and untreated woods.

\section{KEYWORDS}

Fire Propagation test, fire performance indices, fire model, fire hazard, oxygen consumption, heat release rate, material flammability, wall lining.

\section{NOMENCLATURE}

$\mathrm{X}_{02}^{\mathrm{t}}=$ Residual volume fraction of $\mathrm{O}_{2}$ detected in the analyzer following igniter gas combustion at time, ' $t$ '

$\mathrm{Y}_{\mathrm{o} 2}^{\mathrm{t}}=$ Volume fraction of $0_{2}$ detected in the analyzer during the test at time, ' $t$ '

E $=17.2\left(\mathrm{MJ} / \mathrm{m}^{3}\right)$, heat released due to unit volume of $0_{2}$ consumed, referred to $25^{\circ} \mathrm{C}$

$\dot{\mathrm{V}}_{\mathrm{o}} \quad=$ Volume flow rate of unvitiated air into the apparatus, $\left(\mathrm{m}^{3 / \mathrm{s}}\right)$ 


$\begin{array}{ll}\dot{\mathrm{Q}}_{\mathrm{t}} & =\text { Heat Release Rate at time 't' }(\mathrm{kW}) \\ \mathrm{H}_{\mathrm{c}, \text { net }} & =\text { Net heat of combustion, MJ/kg } \\ \mathrm{H}_{\text {eff }} & =\text { Measured average heat of combustion, MJ/kg } \\ \mathrm{HRR} & =\text { Heat Release Rate }\left(\mathrm{kW} / \mathrm{m}^{2}\right) \\ \mathrm{HR} & =\text { Cumulative Heat Released }\left(\mathrm{MJ} / \mathrm{m}^{2}\right) \\ \text { PLA } & =\text { Gypsum Plasterboard, } 12 \mathrm{~mm} \\ \text { PPL } & =25 \mathrm{~mm} \text { Polystyrene backed Gypsum Plasterboard, } 9 \mathrm{~mm} \\ \text { FRC, JC \& JM } & =\text { Fire Retardent Chipboards, } 12 \mathrm{~mm} \\ \text { MFC } & =\text { White Melamine faced Chipboard, } 15 \mathrm{~mm} \\ \text { PLY } & =9 \text { ply Birch Plywood, } 12 \mathrm{~mm} \\ \text { HDBD } & =\text { Hardboard, 12mm }\end{array}$

\section{INTRODUCTION}

The Building Regulations in the UK and N. Ireland refer to lining materials, class 0 , recognised as such by the Fire Propagation test. The test was developed in the $60^{\prime} \mathrm{s}^{\left[\mathrm{H},\left[{ }^{2]}\right.\right.}$ and the objective of the test is to assess a lining material's potential contribution to fire growth in a compartment. A view of the apparatus is shown in Figure 1, along with a description of the salient test procedure. The evaluation criteria defined by fire performance indices relies upon comparing the temperature rises obtained in the effluent stream as a result of the test material burning in a naturally ventilated combustion chamber to that of a specified non combustible material subjected to a similar heating regime.

Recognizing the hazard posed by early heat release ${ }^{[1],[2],[3]}$ by a burning lining material in an enclosure, weightings were applied to the indices to accentuate the early temperature rises. The fire environment severity is defined by reference to a growing irradiance made available 165 seconds into the test whilst a continuous, 14 port, line ignition source impinges on the bottom edge of the sample which itself forms one vertical face $(190 \mathrm{~mm}$ $x 190 \mathrm{~mm}$ ) of the asbestos wood combustion chamber. The pattern of heat release over the 20 minute test is weighted as shown by the following calculation of the performance indices:

$$
I=\sum_{1 / 2}^{3}\left(\frac{T_{m}-T_{c}}{10 t}\right)+\sum_{4}^{10}\left(\frac{T_{m}-T_{c}}{10 t}\right)+\sum_{12}^{20}\left(\frac{T_{m}-T_{c}}{i_{2}}\right)
$$

$\mathrm{I}=$ overall index of performance

$i_{1}=$ calculated at $1 / 2$ minute intervals over period $30(\mathrm{~s})-180(\mathrm{~s})$ (highest weighting)

$\mathrm{i}_{2}=$ calculated at 1 minute intervals over period $240(\mathrm{~s})-600(\mathrm{~s})$ (intermediate weighting)

$\mathrm{i}_{3}=$ calculated at 1 minute intervals over period $720(\mathrm{~s})-1200(\mathrm{~s})$ (lowest weighting)

' $\mathrm{t}$ ' = time in minutes from the start of the test

$\mathrm{T}_{\mathrm{m}}=$ temperature rise recorded for the material at time ' $\mathrm{t}$ '

$\mathrm{T}_{\mathrm{c}}=$ temperature rise recorded for the non-combustible standard at time ' $t$ '.

A material satisfying Building Regulations Class 0 would have to satisfy the condition that $\mathrm{i}_{1} \leq 6$ and $\mathrm{I} \leq 12$. 
An earlier assessment by Hinkley et $\mathrm{al}^{\left[{ }^{[3]}\right.}$ first presaged the notion of assessing heat release by monitoring oxygen variations in the combustion stream. The advent of the Cone Calorimeter ${ }^{[4],[5]}$ making available numerical fire data, concurrent with EEC activity with regard to rationalisation of national fire tests, provided the impetus for a further investigation of the Fire Propagation test as its development had arisen from experience of building fires ${ }^{[1],[2],[3],[4],\{5]}$.

\section{MATERIALS AND INVESTIGATIONS}

Typical woods and plasterboard wall lining materials noted in the nomenclature section were used for the investigations.

The first stage involved material testing under standard conditions. A strain gauge load cell of $100 \mathrm{~kg}$ capacity was then incorporated to monitor mass loss. The load signal cell was amplified and fed to a strip chart recorder and mass loss was deduced from precalibrated weights. The oxygen consumption rate was monitored by an electro-chemical cell system by sampling part of the effluent stream at a rate of $0.7 \mathrm{~L} / \mathrm{min}$, using a copper ring sampler located under the chimney cowl. A sampling train consisting of glass wool, glass filter paper and silica gel was used to clean the product stream of particulates, vapours and moisture. Attempts to scrub the $\mathrm{CO}_{2}$ from the sample stream ran into difficulties similar to $\operatorname{Tran}^{[6]}$. It was difficult to tell when the absorbent material was exhausted and clogging of the lines were compounded by inline instrument restrictions.

A review of the extant literature on the oxygen consumption principle ${ }^{[7],[8],[9]}$ indicated that HR determinations were achievable by measuring air flows into the apparatus. This was investigated by reference to methane gas combustion in the apparatus (vide infra). The thermal environment in the test enclosure was also investigated as the only available data is due to Hinkley et $a^{[3]}$ (Figure 2). A copper pellet coated with black paint of known emittance $(0.97)$ was used to estimate the heat flux history on the surface of a Calcium Silicate board. The copper disc was calibrated for heat fluxes in the cone calorimeter system which was itself calibrated against a gardon gauge fluxmeter.

\section{RESULTS AND DISCUSSION}

Hinkley et al derived theoretical effluent gas flow rates through a flue induced by natural convection, obtaining a maximum flow of $1.1 \mathrm{~g} / \mathrm{s}$ at $290^{\circ} \mathrm{C}$ and $1 \mathrm{~g} / \mathrm{s}$ at flue gas temperatures of $80^{\circ} \mathrm{C}$ above an ambient of $17^{\circ} \mathrm{C}$. Recalculating these for ambient air at $17^{\circ} \mathrm{C}$ resulted in values of $8.2-9.1 \times 10^{-4}\left(\mathrm{~m}^{3} / \mathrm{s}\right)$ of air flow into the combustion chamber. The air flow into the apparatus was then predicted from the combustion stoichiometry of methane gas as indicated in Table 1 . The theoretical minimum air requirement for complete combustion of $\mathrm{CH}_{4}$ gas is as follows:

$$
\mathrm{CH}_{4}+2\left(3.76 \mathrm{~N}_{2}+\mathrm{O}_{2}\right) \rightarrow \mathrm{CO}_{2}+2 \mathrm{H}_{2} \mathrm{O}+7.52 \mathrm{~N}_{2}
$$

By varying the methane gas flow to the combustion chamber and monitoring the combustion products at the gas analyzer, theoretically expected $\mathrm{O}_{2}$ concentrations were compared to measured values for assumed air flow rates to the chamber. 


\begin{tabular}{||c|c||}
\hline $\begin{array}{c}\text { Test Period } \\
(\mathrm{secs})\end{array}$ & \multicolumn{1}{c|}{$\begin{array}{c}\text { Average Flow Rate } \\
\left(\mathrm{m}^{3} / \mathrm{s}\right)\end{array}$} \\
\hline $0-120$ & $8.8 \times 10^{-4}$ \\
$120-200$ & $9.4 \times 10^{-4}$ \\
$200-400$ & $9.7 \times 10^{-4} \pm 1.5 \%$ \\
$400-750$ & $9.9 \times 10^{-4} \pm 1 \%$ \\
$750-1200$ & $1.04 \times 10^{-3} \pm 6 \%$ \\
\hline
\end{tabular}

A non-combustible $\mathrm{CaSiO}_{3}$ board was used for the tests. The methane gas flow was varied from $0.9-1.9 \mathrm{l} / \mathrm{min}$. Application of power to the radiant heaters at 165 seconds into the test clearly causes an increase in the air flow induced into the chamber. Variations in burning rate inside the combustion chamber will result in slight variations of induced air flow to the chamber. The figures in Table 1, were averaged from $\mathrm{CH}_{4}$ flows of 0.9 to 1.9 $1 / \mathrm{min}$, representing heat input rates of $0.55-1.1 \mathrm{~kW}$. Observation of the diffusion flamelets from the line burner saw the initially clear/blue methane flame lengthening, bushing and changing to a violet/yellow colour with time. This was exacerbated at higher fuel flow rates, suggesting temporal combustion efficiency variations.

After accounting for the oxygen consumption due to the igniter gas, the following simplified equation was used to monitor HRR solely due to sample combustion:

$$
\dot{Q}_{t}=\left[\frac{X_{O 2}^{t}-Y_{O 2}^{t}}{1-Y_{O_{2}}^{t}}\right] * E * \dot{V}_{o}
$$

Equation 41 of Parker $^{[8]}$ may be used for more accurate determinations, if a knowledge of the combustion stoichiometry of the igniter towngas fuel is known. The Parker equation also accounts for $\mathrm{CO}$ in the product gas stream indicating less than total combustion as assumed in the simplified analysis. Unfortunately the electro-chemical $\mathrm{CO}$ cell in the gas analyzer was overwhelmed by the $\mathrm{CO}$ evolution rate at approximately 8-10 minutes into the test for the woody materials tested. It has been estimated ${ }^{[10]}$ that for a completely unknown material ignoring molar changes in the flue gases, and assuming complete combustion, the maximum error in HRR measurements is $<20 \%$.

Heat release rates were computed for known flows of methane as indicated:

1. For a $\mathrm{CH}_{4}$ flow rate of $0.9 \mathrm{l} / \mathrm{min}$, corresponding to a heat input of 550 watts and net heat of combustion of $\mathrm{CH}_{4}$ at $36.7\left(\mathrm{MJ} / \mathrm{m}^{3}\right)$, the calculated $\mathrm{HRR}$ ranged from an average of $544 \pm 3 \%$ at times $<400$ seconds to an average of $512 \pm 6 \%$ watts for the last 450 seconds.

2. For a $1.91 / \mathrm{min} \mathrm{CH}_{4}$ flow corresponding to a heat input of 1162 watts, the computed average HRR values were $1144 \pm 10 \%$ watts at times $<400$ seconds falling to $999 \pm$ $6 \%$ watts for the last 450 seconds.

Overall, the HRR trends suggest that at times $>8-10$ minutes into the test, materials of high 
burning rates would suffer reduction in heat release rates. Assessment of HRR parameters require a knowledge of the thermal environment experienced by the sample. From considerations of igniter gas flows and temporal irradiance from the electrical element heaters to the internal volume of the combustion chamber $(0.19 \times 0.19 \times 0.09) \mathrm{m}^{3}$, Table 2 , depicts the maximum heat fluxes impinging on the sample surface.

TABLE 2. Estimated Heat Fluxes Averaged Over the Sample Surface in the Test Chamber

\begin{tabular}{|c|c|}
\hline $\begin{array}{c}\text { Test Period } \\
\text { (secs) }\end{array}$ & $\begin{array}{c}\text { Maximum Estimated Heat Flux } \\
\left(\mathrm{kW} / \mathrm{m}^{2}\right)\end{array}$ \\
\hline $0-165$ & 14.7 \\
$165-300$ & 64.6 \\
$300-1200$ & 56.2 \\
\hline
\end{tabular}

Measurements of heat fluxes were obtained at the midpoint and towards the top surface of a Calcium Silicate board, opposite one of the two electric elements in the chamber. The correspondence with the heat flux profile and flux values over the first 5-6 minutes of the test with Hinkley's measurements are striking. Although the thermal capacity of the Supalux board is lower than that of Hinkley's asbestos wood, and would therefore experience a higher rate of heat transfer, the fluxes noted after 6 minutes appears high by reference to the maximum heat fluxes derived in table 2. The primary reason is that the coating on the pellet flux meter flaked off at fluxes $>45\left(\mathrm{~kW} / \mathrm{m}^{2}\right)$ and then on violates the validity of the heat flux calibrations.

The fire performance indices derived from the Fire Propagation test is shown by Table 3 and the heat release rate parameters computed from Eqn (3) is reproduced in Table 4.

Representative cumulative mass loss curves and HRR profiles obtained for each of the categories of materials are shown in Figures 3.

Reference to the indices $i_{2}, i_{3}$ and the overall composite I suggest a categorisation of material type indicated by plasterboards, fire retarded and untreated wood. Figure 2 shows the period over which the indices $i_{1}, i_{2}$ and $i_{3}$ are computed. The HRR and mass loss profiles show that the $i_{1}$ index encompasses a period of localised heating of the material to flaming ignition, including the early stages of pyrolytic decomposition. The $i_{1}$ period reflects an ignitable materials' heat contribution in the early stages of fire spread when the intensity of flame radiation heating from nearby burning objects in a compartment is small and suggests a complex interplay of thermal inertia, ignition thresholds and heat release potential dictated by it's calorific value.

Table 4 illustrates this by reference to the cumulative heat release at 5 minutes. Ignition times are in the order, Fire Retardent Chipboards $>$ Plasterboards $>$ Melamine faced Chipboard $>$ Hardboard $>$ Plywood. The MFC board decomposes by the preferential promotion of charring ring condensation reactions, reflected by the indices and heat release value at 5 minutes. Comparatively, plywood contributes significant heat relatively early as indicated by a large numerical index $i_{1}$, consequently resulting in a large $I$ value. The trends are reflected by the measured heat release figures. 
TABLE 3. Performance Indices in the Fire Propagation Test

\begin{tabular}{||l|r|r|r|r|c||}
\hline Material & \multicolumn{1}{|c|}{$\mathrm{i}_{1}$} & \multicolumn{1}{c|}{$\mathrm{i}_{2}$} & \multicolumn{1}{c|}{$\mathrm{i}_{3}$} & \multicolumn{1}{c||}{$\mathrm{I}$} & $\begin{array}{c}\text { BS 476 Pt. 7 } \\
\text { class. }\end{array}$ \\
\hline PLA & 2.15 & 1.03 & 0.45 & 3.60 & 1 \\
PPL & 1.93 & 1.70 & 0.60 & 4.10 & 1 \\
FRC,JC & 1.95 & 3.01 & 3.14 & 8.12 & 1 \\
FRC,JM & 2.51 & 3.20 & 2.66 & 8.45 & 1 \\
MFC & 3.09 & 14.50 & 5.00 & 23.87 & 2 \\
HDBD & 10.86 & 18.74 & 5.30 & 34.61 & 3 \\
PLY & 18.24 & 19.43 & 5.30 & 42.95 & 4 \\
\hline \hline
\end{tabular}

NB BS 476 Pt. 7 is a Surface Spread of Flame test for wall and ceiling linings.

TABLE 4. Heat Release Rate Parameters in the Fire Propagation Test

\begin{tabular}{||l|c|c|c|c||}
\hline Material & $\begin{array}{l}\text { HR at } 5 \mathrm{~min} \\
\left(\mathrm{MJ} / \mathrm{m}^{2}\right)\end{array}$ & $\begin{array}{l}\text { Averaged } \mathrm{H}_{\text {eff }} 5 \\
\min \left(\mathrm{MJ} / \mathrm{m}^{2}\right)\end{array}$ & $\begin{array}{l}\mathrm{HR} \text { at } 20 \mathrm{~min} \\
\left(\mathrm{MJ} / \mathrm{m}^{2}\right)\end{array}$ & $\begin{array}{l}\text { Averaged } \mathrm{H}_{\text {eff }} 20 \mathrm{~min} \\
(\mathrm{MJ} / \mathrm{kg})\end{array}$ \\
\hline PLA & 1.27 & $10.25^{*}$ & 9.46 & $11.10^{*}$ \\
PPL & 1.13 & $10.40^{*}$ & 9.06 & $10.10^{*}$ \\
FRC,JC & 0.93 & 4.58 & 12.30 & 3.81 \\
FRC,JM & 1.14 & 4.82 & 11.26 & 4.13 \\
MFC & 5.63 & 17.30 & 23.02 & 5.08 \\
HDBD & 5.03 & 9.28 & - & - \\
PLY & 10.50 & 10.94 & 53.75 & 10.75 \\
\hline
\end{tabular}

NB 1. All values in table 3 are averages of 5 results and of 2 results in Table 4. 2.(*) $\mathrm{H}_{\text {eff }}$ values corrected for weight loss due to water release from gypsum

Table 5 is a summary of mass burning rates, assuming maximum combustion, estimated from the linear part of the observed volatile cum solid phase combustion period of the mass loss curves.

The mass loss curves generally show a linearly increasing mass loss rate profile following 4-5 minutes into the test. This corresponds to a period of sharply rising heat flux to the material surface as indicated by Figure 2 and just entering the initial period represented by index $\mathrm{i}_{2}$. An average value of $\mathrm{H}_{\mathrm{c}, \text { net }}$ of $17.8 \mathrm{MJ} / \mathrm{m}^{2}$ was used for wood ${ }^{[6]}$ where this was estimated from an OSU HR apparatus at a heat flux of $25 \mathrm{~kW} / \mathrm{m}^{2}$ in a vertical configuration. A value of $16.09 \mathrm{MJ} / \mathrm{m}^{2}$ was assumed for the cellulosic paper facing of the plasterboard materials. A time weighted average irradiance of $29 \mathrm{~kW} / \mathrm{m}^{2}$ to the sample surface was estimated, using Hinkley's measurements and an average of $17 \mathrm{~kW} / \mathrm{m}^{2}$ noted for $40 \%$ of the time at 5 minutes into the test. Early heat release is aided by external irradiances $>$ $5 \mathrm{~kW} / \mathrm{m}^{2}$ noted by char spread rates ${ }^{[13]}$ and is driven mainly by the material's flames. The 5 minute HR figures are thus low compared to cone HR figures of $27-35 \mathrm{MJ} / \mathrm{m}^{2}$ for irradiances at $20-30 \mathrm{~kW} / \mathrm{m}^{2}$. The effective heat of combustion for the plasterboard materials have been corrected for weight loss due to $\mathrm{H}_{2} \mathrm{O}$ release from the gypsum material. In 
general, the reported $\mathrm{H}_{\text {eff }}$ values approach theoretical values of net heat of combustion and for plywood ${ }^{[11],[12]}$ and hardboard ${ }^{[12]}$ indicate values limited by ventilation control.

Table 5. Estimated Theoretical Heat Released Based on Measured Mass Burn Rates

\begin{tabular}{||c|c|c|c|c|c||}
\hline \multirow{3}{*}{ Material } & \multicolumn{2}{|c|}{ HR over mass burn period } & \multicolumn{2}{c||}{$\begin{array}{c}\text { Estimated combustion } \\
\text { efficiencies (\%) }\end{array}$} & \multirow{2}{*}{$\begin{array}{c}\text { Cumulative } \\
\text { mass loss } \\
(\%)\end{array}$} \\
\cline { 2 - 5 } & $\begin{array}{c}\text { At } 5 \mathrm{~min} \\
\left(\mathrm{MJ} / \mathrm{m}^{2}\right)\end{array}$ & $\begin{array}{c}\text { Linear mass burn } \\
\text { period }\left(\mathrm{MJ} / \mathrm{m}^{2}\right)\end{array}$ & At 5 min & $\begin{array}{c}\text { Linear mass } \\
\text { burn period }\end{array}$ & \\
\hline PLA & 1.96 & 9.42 & 65.00 & 100.00 & 8.14 \\
PPL & 1.73 & 10.93 & 65.00 & 83.00 & 10.46 \\
FRC,JC & 3.80 & 42.30 & 29.00 & 42.30 & 22.00 \\
FRC,JM & 3.72 & 31.40 & 30.60 & 35.60 & 21.00 \\
MFC & 5.80 & 67.20 & 97.00 & 34.26 & 43.40 \\
HDBD & 9.65 & 80.00 & 52.00 & - & 65.30 \\
PLY & 17.10 & 60.20 & 61.00 & 89.29 & 52.00 \\
\hline \hline
\end{tabular}

The computed HR values (Table 5) over the linear mass burn period ( $\sim 300-1000$ (s) and $600 / 660$ (s) for PLA and PPL) are similar to the cone HR values at similar time weight averaged fluxes of $20-30 \mathrm{~kW} / \mathrm{m}^{2},\left(62-67 \mathrm{MJ} / \mathrm{m}^{2}\right.$ for $\mathrm{MFC}, 77-92 \mathrm{MJ} / \mathrm{m}^{2}$ for HDBD and 58$64 \mathrm{MJ} / \mathrm{m}^{2}$ for PLY). The cone values for the FRC chipboards are $5-12 \mathrm{MJ} / \mathrm{m}^{2}$ at $35-40$ $\mathrm{KW} / \mathrm{m}^{2}$ where flaming was observed to intensify in the Fire Propagation test and the values of $11-12 \mathrm{MJ} / \mathrm{m}^{2}$ at 20 minutes in the latter test are indicative of this. Thus the low combustion efficiencies noted for these materials. The HRR figures by $0_{2}$ consumption for both MFC and Hardboard at 20 minutes are too low to trust, due to saturation of the electro-chemical cells in the analyser following repeated runs and further due to ventilation and fluid flow restrictions for intensely burning materials of long burn duration. Ongoing work on the part 6 and cone systems will seek to expand the reported pilot study. The $i_{2}$ index period sees rapidly rising heat fluxes reflected by critical mass fluxes required for sustained piloted ignition $\left(1-4 \mathrm{~g} / \mathrm{s} / \mathrm{m}^{2}\right)^{[9]}$.

Assessment of the adequacy of combustion air was estimated by defining a ventilation parameter as follows:

$$
\phi=\frac{\left(\dot{m}_{\text {air }} / r_{o}\right)}{\dot{m}_{\text {fuel }}}
$$

$\dot{m}_{\text {air }}=$ air flow rate (measured average of $1.05 \mathrm{~g} / \mathrm{s}$ with a maximum of $1.2 / \mathrm{g} / \mathrm{s}$ )

$r_{0}=$ stoichiometric mass of air required to burn $1 \mathrm{~g}$ of fuel $\left(5.7 \mathrm{~g}\right.$ for wood $\left.{ }^{[12]}\right)$

$\dot{m}_{f u e l}=$ averaged fuel gasification rates for the fuel $(0.2-0.3 \mathrm{~g} / \mathrm{s}$ for the woody materials tested)

Hence, for idealised combustion conditions, the ventilation rates are just adequate to $67 \%$ of the required rate at the highest gasification rates noted (hardboard; $\sim 0.3 \mathrm{~g} / \mathrm{s}$ ). In essence, the $i_{2}$ period and early $33 \%$ of the $i_{3}$ period represent the combustion period from ignition to flameout noted in the cone calorimeter. 
The heat flux rises slowly in the $i_{3}$ period. For woody materials this is represented by subsurface volatile and surface char combustion. The fire retarded chipboard surface with its uniform mottled black surface following pyrolysis in the $i_{1}$ period reflects the heat flux/time curve closely and clearly identifies heat flux absorbtion at the surface as the primary influence on combustion intensity.

Thus, the Fire Propagation Test provides a detailed picture of the changing fire response of the test material to a varying environment as seen by the characteristic heat release profiles of the three material categories noted. The heat release response features are also reflected in the relative magnitudes of the individual indices of fire performance returned in the test.

Rogowski's developmental work ${ }^{1}$ on the Fire Propagation test and the results of the current study suggest a relationship between $i_{I}$ and $I$ which becomes deceleratively non-linear for higher values of $i_{1}$ and $I$. The latter non linearity may reflect combustion limitations noted in the system for materials of high heat potential which gasify at high rates up to the $i_{3}$ period and thus suffer combustion rates limited by the available ventilation ${ }^{[12]}$.

\section{CONCLUSIONS}

Analysis of the fire performance indices by reference to HRR, mass and heat flux measurements have confirmed the veracity of the traditional evaluation of a lining material's fire performance in the Fire Propagation test.

Owing to the relatively low ventilation rates noted, the sensitivity towards oxygen depletion is enhanced making the test particularly suited for evaluating of materials of limited combustibility. Higher ventilation rates than available by natural ventilation is required for estimating HRR beyond 10 minutes into the test for high HRR, long burn materials.

The characteristic burning signature indicated by the test materials' HRR profile is clearly tied to the variation in attacking heat flux as best illustrated by the fire retardant chipboard. This highlights the effectiveness of the test in evaluating materials that pose a fire hazard whilst approaching flashover and in providing data for fire modelling.

Tests in a scaled compartment at Ulster University ${ }^{[13]}$ has highlighted the importance of early heat release and burning close to flashover conditions in contributing towards the probability of flashover.

The Fire Propagation fire model effectively simulates fire conditions in a compartment from the early pre-flashover stage to near flashover conditions by reference to the changing thermal ${ }^{[4]}$ and combustion environment. This suggests the modified test has utility in evaluating transitions of combustion mechanisms which will result in modified $\mathrm{CO}$, smoke and heat release rates ${ }^{[14]}$ and thus to the perceived hazard. Peak $\mathrm{CO}$ measured in the Fire Propagation test ${ }^{[13]}$ are comparatively higher than those seen in a reduced ventilation version of an OSU HR apparatus ${ }^{[15]}$, by a factor of three to four times for plasterboard and fire retarded wood respectively and up to an order of magnitude higher for plywood. 


\section{ACKNOWLEDGEMENT}

The work reported here was supported by the Department of the Environment, London. Thanks are also due to graduate student Tin Wai Chan, the research team, Mr. S. Ames, Fire Research Station, UK and Carol at the Fire SERT Centre for assistance rendered.

\section{REFERENCES}

1. Rogowski, B.F.W., "The Fire Propagation Test, it's Development and Application". Fire Research Technical Paper No. 25, 1970.

2. Malhotra, H.L., Fire Safety in Buildings. Report for Fire Research Station, BRE, DOE, 1986.

3. Hinkley, P.L., Wright, G.H. and Wadley, A. Fire Research Notes Nos. 709 and 710. FRS, May 1968.

4. Babrauskas, V, "Specimen Heat Fluxes for Bench Scale Heat Release Rate Testing". Interflam '93 pp.57-74, 1993.

5. Blachere, G. Tephany, H., Trottein, Y., "Fire Reaction Tests in the EEC". Aux IBBat, Report 744/III/85-EN.

6. Tran, H.C., "Rates of Heat and Smoke Release of Wood in an Ohio State University Calorimeter". Fire and Materials, Vol. 12, pp.143, 1986.

7. Tsuchiya Y., "Methods of Determining Heat Release Rate. State of the Art." Fire Safety Journal 5, pp.49, 1982.

8. Parker, W.J., "Calculations of the Heat Release Rate by Oxygen Consumption for Various Applications". Journal of Fire Sciences, Vol. 2, pp. 380, Sept/October 1984.

9. Janssens, M., and Parker, W.J., "Oxygen Consumption Calorimetry" in Heat Release in Fires. Eds., Babrauskas, V. and Grayson, G.J., pp.31, Elsevier Science Publishers Ltd., 1992.

10. Ahonen, A. Weckman, $\mathrm{H}$ and Yli-Penttila, M., "Application of Oxygen Calorimetry to Non Combustibility Testing". Fire and Materials, Vol. 9, No. 3, pp. 135, 1985.

11. Tran, H.C., "Experimental Data on Wood Materials", in Heat Release in Fire, Babrauskas, V. and Grayson, G.J., pp.307, Elsevier Science Publishers Ltd., 1992.

12. Janssens, M., "Room Fire Models" in Heat Release in Fires, Eds. Babrauskas, V. and Grayson, G.J., pp. 113, Elsevier Science Publishers Ltd., 1992.

13. Azhakesan Akasha, M., "An Initial Assessment of Reaction to Fire Material Classification and Translatability". Fire SERT Centre, Dept. of Building and Environmental Engineering, University of Ulster. Nov. 1992. 
14. Tsuchiya, Y. and Mathieu, J.F., "Heat, $\mathrm{CO}$ and Smoke Release Rates of Plywood Under a Depleted Oxygen Atmosphere; an Experimental Study Using an OSU Heat Release Rate Apparatus". Proc. of the Third International Symposium. Fire Safety Science, pp. 605, 1991.

15. Tsuchiya, $Y$ and Mathieu, J.F. "Measuring Degrees of Combustibility Using an OSU Apparatus and Oxygen Depletion Principle". Fire Safety Journal 17 pp. 291, 1991.

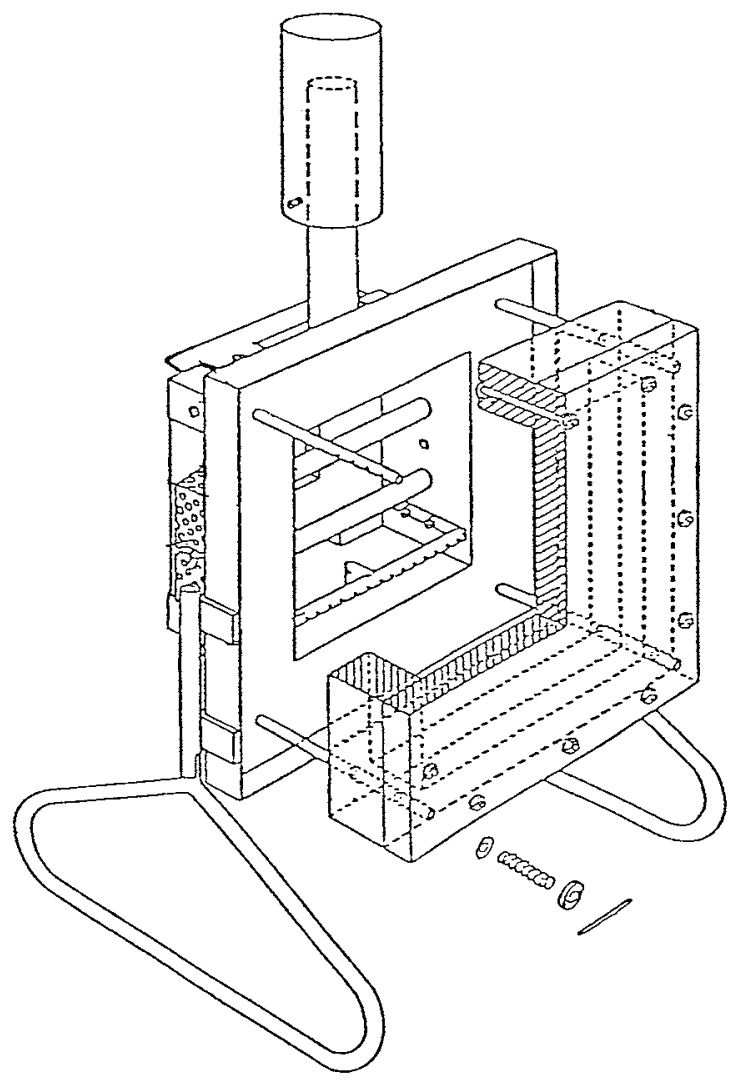

FIG 1. The Fire Propagation Test, BS 476, Pt.6

Igniter fuel is metered at $530 \mathrm{~W}$ for the entire test duration of 20 minutes. Electric heaters are switched on at 165 seconds supplying $1800 \mathrm{~W}$ initially and reduced to $1500 \mathrm{~W}$ at 5 minutes. The apparatus is calibrated for specified effluent gas temperature tolerances with a reference Monolite N.C. board. Test specimens are vertically held with an exposed surface area of $190 \mathrm{~mm}^{2}$. 


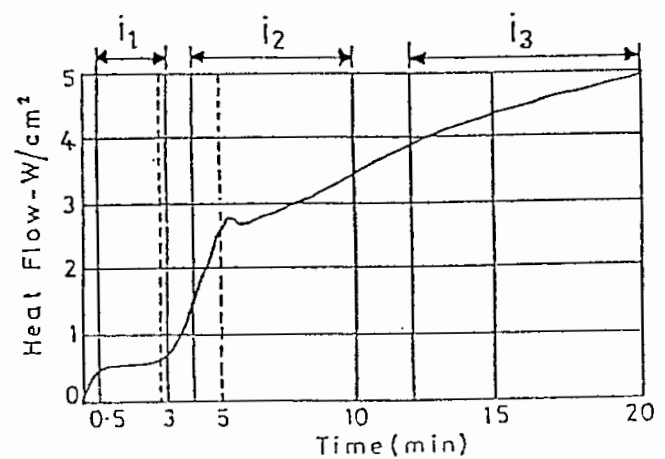

Gross heat flow lo asbestos wood (Ref: Hinkley et al)

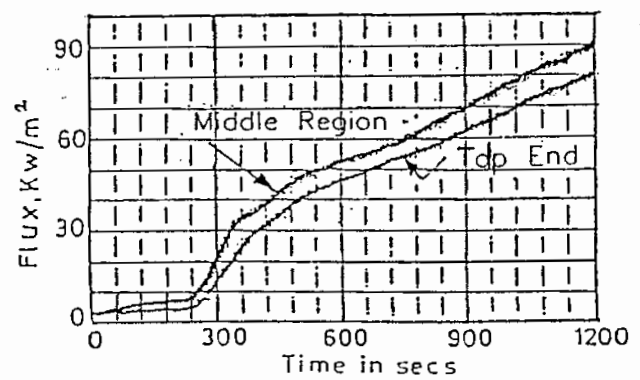

Gross heal flow to Supalux board

FIG 2. Heat Flux Measurements on Non-Combustible Surfaces 

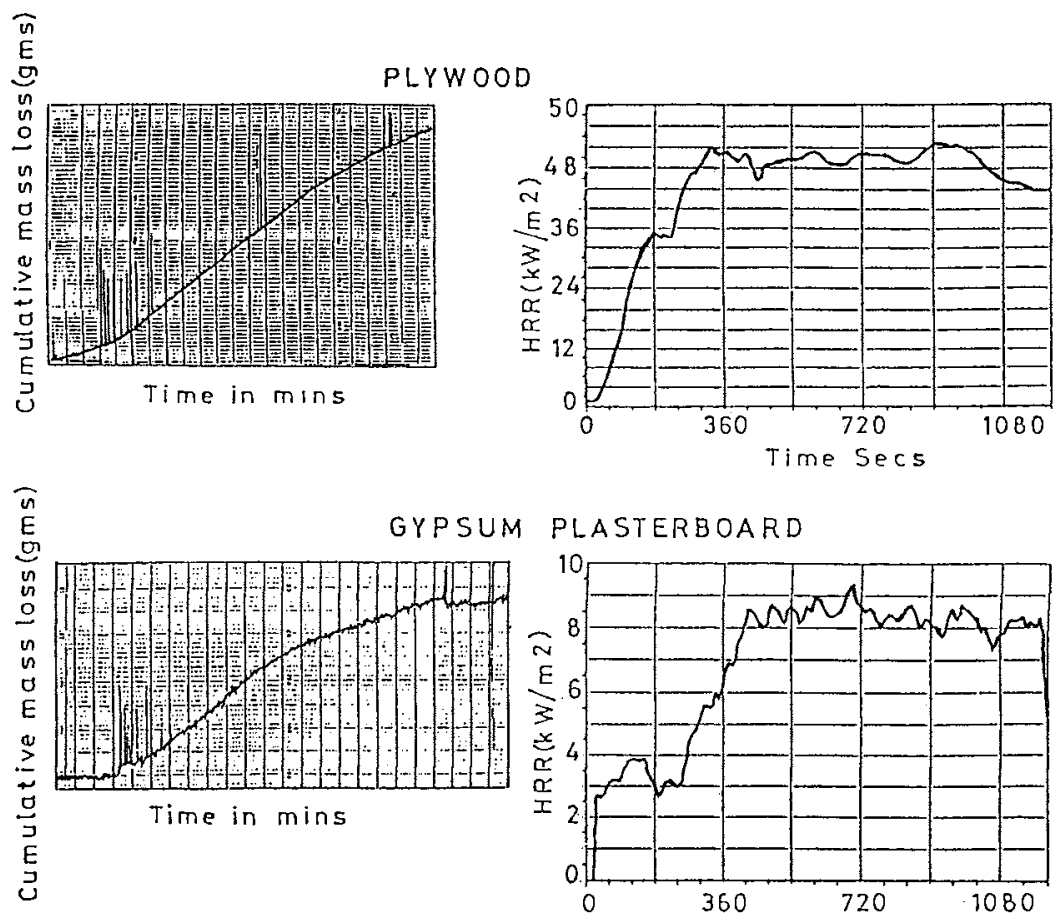

\section{PLASTERBOARD}
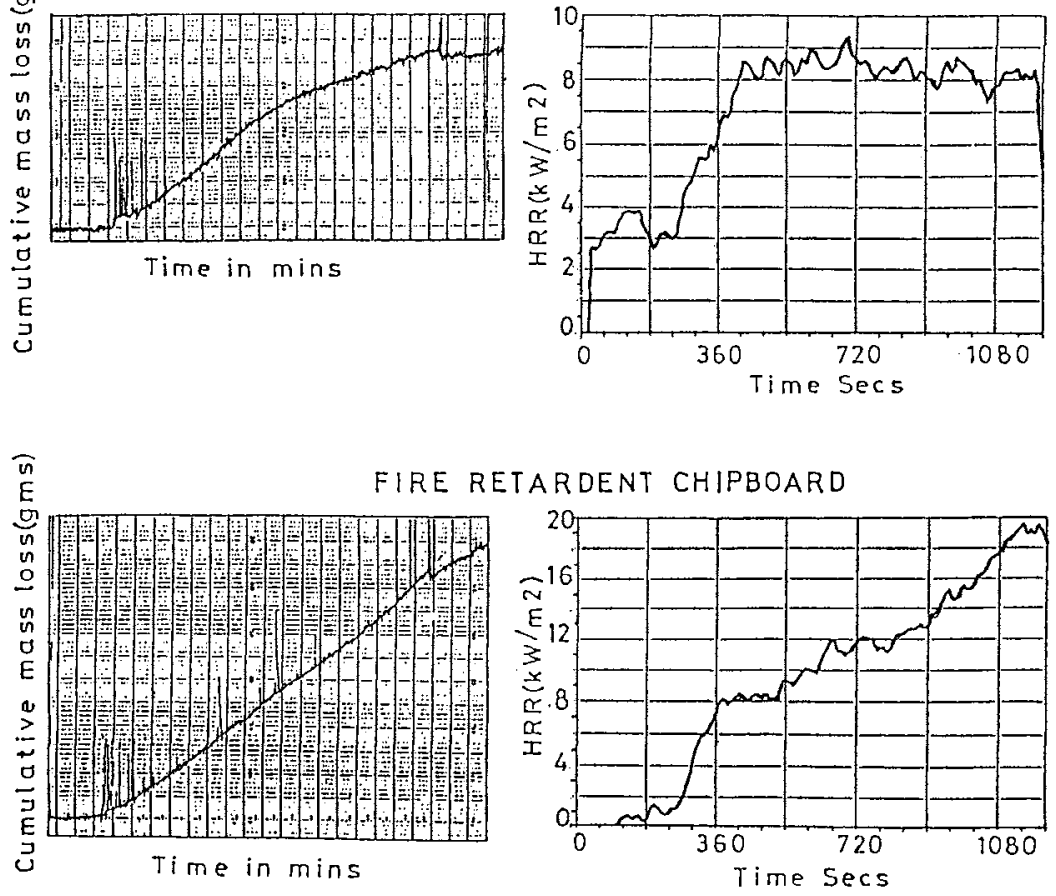

FIG 3. Cumulative Mass Loss and HRR Profiles 